\title{
Food and nutrition policies: what's being done in Turkey
}

\author{
Gülden Pekcan* \\ Department of Nutrition and Dietetics, Division of Community Nutrition, Hacettepe University, 06100 Ankara, Turkey
}

\begin{abstract}
Objective: The aim of the present paper is to describe the development of the National Plan of Action for Food and Nutrition (NPAFN) for Turkey.

Design: Access to a safe and healthy variety of food, a fundamental human right, was stressed by the International Conference on Nutrition and by the World Food Summit. In the International Conference on Nutrition in December 1992, one major commitment was the preparation of NPAFN. The NPAFN for Turkey was designed according to this commitment.

Setting: Turkey.

Results: To this end, under the coordination of the State Planning Organization, a Working Committee Report for National Food and Nutrition Strategy of Turkey was prepared and published, with the participation of different sectors. The goal of the prepared National Food and Nutrition Strategy for Turkey is to protect and promote health through and healthy nutrition and reduce the burden of diseases, while contributing to socio-economic development and a sustainable food security. Conclusion: In Turkey the NPAFN was developed and implementation has initiated. Nearly for all the actions, related projects are being developed.
\end{abstract}

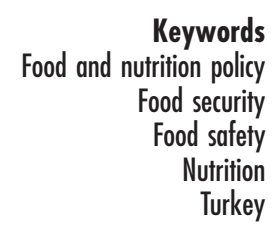

Access to a safe and healthy variety of food, a fundamental human right, was stressed by the International Conference on Nutrition (ICN; 1992, 1996) and by the World Food Summit (WFS;1992, 2002). In the ICN in December 1992, one major commitment was the preparation of a National Plan of Action for Nutrition (NPAN). In the WFS (1996, 2002), countries and the European Community pledged their political will and their common and national commitment to 'achieving food security for all and to an on-going effort to eradicate hunger in all countries, with an immediate view to reducing the number of undernourished people to half their present level no later than $2015^{1,2}$.

Following the ICN and WFS, depending on the commitments, Turkey has given priority to develop a number of activities and plan of actions. The development and implementation of activities demand multisectoral and intersectoral coordinated efforts of various ministries, institutions, the private sector, international and regional organisations, universities, the food industry and non-governmental organisations (NGOs), etc. $^{3}$. To this end, under the coordination of the State Planning Organization (SPO), a Working Committee Report for National Food and Nutrition Strategy of Turkey was prepared and published, with the participation of different sectors ${ }^{4}$.

\section{Country background}

In many reports and publications the nutrition and health problems, also the food situation of Turkey (agricultural production, land use, food security and economy, trends in food supply) were reviewed ${ }^{4-9}$.

\section{Geographic and demographic profiles, and bealth status}

Some variables of Turkey are given in Table $1^{10,11}$.

\section{Food and nutrition situation}

\section{Food security}

Turkey is a major agricultural producer. With respect to its climate and land nature, Turkey is suitable for the production of various products. The share of the crop production in agricultural production is $73.5 \%$, the share of wheat in grains is $67 \%{ }^{4}$. Wheat is staple food for the Turkish people. The major percentage of energy comes from bread (44\%) and bread and other cereals (58\%) $)^{7,9}$. According to FAO Food Balance Sheets, Turkish people appeared to be well nourished. Dietary energy supply was estimated as $3500 \mathrm{kcal}$ per person ${ }^{9}$. The total protein consumption per capita was estimated as high, but maldistribution and the poor quality of much of the food consumed in Turkey are not properly demonstrated in food balance sheets. 
Table 1 Some variables of geographic, demographic and health status of Turkey ${ }^{10,11}$

\begin{tabular}{lc}
\hline Variables & \\
\hline Geography & \\
$\quad$ Surface area (square km) & 774815 \\
Demographic profile & \\
$\quad$ Total population (million, 2000 census) & 67.4 \\
Population below 15 years (\%) & 29.1 \\
Population above 65 years (\%) & 6.9 \\
Crude birth rate (per thousand) & 22 \\
Crude death rate (per thousand) & 7 \\
Total fertility rate (children per woman) & 2.23 \\
Health status & \\
Infant mortality rate (per 1000) (1998; 2003) & $42.7 ; 28.7$ \\
Under-5 mortality rate (per 1000) (1998; 2003) & $52 ; 37$ \\
Breast-feeding practices & \\
$\quad$ Breast-feeding rate (\%) (1998; 2003) & $95 ; 97$ \\
$\quad$ Exclusive breast-feeding (\%) (1998; 2003) & $1.3 ; 20.8$ \\
$\quad$ Mean duration (months) (1998; 2003) & $13.7 ; 14.9$ \\
$\quad$ Median duration (months) (1998; 2003) & $12 ; 14$ \\
\hline
\end{tabular}

The most important parameter influencing the food consumption pattern is income level and lack of knowledge. Low-income families consume more bread, while high-income families consume more meat and meat products. This indicates that the problem is not the unavailability of foods, but its maldistribution among socioeconomic, gender and age groups.

\section{Food safety}

Food safety is an assurance that food will not cause harm to the consumer when it is prepared and/or eaten according to its intended use. Protecting consumers through improved food quality and safety, by strengthening food control systems, promoting food manufacturing practices and educating food sellers and consumers about appropriate food handling, is important. The role of government in developing food safety programmes is very important and should be implemented at every stage of food production 'from farm to fork ${ }^{4,12,13}$. In the process of integration with the European Union (EU), the government prepared legal arrangements. Within this context and by considering the situation in the country and examining studies and recommendations of international agencies, the Decree Having the Force of Law No. 560, concerning the 'Production, Consumption and Inspection of Food Stuffs', was enacted by 1995. It contains provisions for hygienic and technical production, processing, preservation and storage of food ${ }^{14}$. In June 2004, the 'Food Law' was enacted ${ }^{15}$.

\section{Nutrition and bealth problems}

The prevalence of malnutrition is high among under- $5 \mathrm{~s}$ has been (stunted: $12.2 \%$, underweight: $3.9 \%$ ), although the rate has decreased during the last years ${ }^{10,11}$. A decline in infant mortality rate has been observed, but it is still very high $^{10,11}$. Micronutrient deficiencies (iron deficiency anaemia, iodine deficiency disorders, etc.) are one of the main nutritional problems. Approximately half of preschool children and pregnant and lactating women, and one-third of school children, have iron deficiency anaemia $^{16-18}$. The prevalence of enlarged thyroid was reported in a review publication as 30.3\% among 6-12 year old children ${ }^{7,8}$. In 1995 , the consumption rate of iodised salt was $18.2 \%{ }^{19}$. In 1998, iodisation of household salt became mandatory ${ }^{20}$. The usage of household iodised salt raised to $62 \%$ in 2002 and to $70 \%$ in $2003^{11,21}$. Dietrelated chronic diseases such as obesity, cardiovascular diseases, hypertension, type II diabetes, dental caries and some types of cancers are major health problems $s^{4,7}$

The results of national and local surveys indicate that the average diet was adequate to meet the recommended daily intake of energy and most of the nutrients, while animal protein, calcium, vitamin $\mathrm{A}$ and riboflavin are lower than recommended intake. No significant changes were observed in average food consumption amounts within years ${ }^{4,7,22-24}$.

\section{Main problems and constraints}

Turkey has been implementing actively some special programmes on maternal and child health, family planning and community-based food and nutrition programmes for a long time, like in many countries ${ }^{19}$. Some of the main problems and constraints faced are given below.

\section{National food and nutrition survey}

Turkey is in need of a nationwide food consumption, health and nutrition survey. The last surveys were held in 1974 and $1984^{22,23}$. Since than no nationwide food consumption, nutrition and health survey has been held. Turkey has educated manpower, knowledge and experience on how to do such surveys. Although a National Food and Nutrition Survey was planned to be conducted, due to financial constraints it has been postponed.

\section{Nutrition education and increasing awareness of bealtby nutrition}

Training of health personnel and public education on health and nutrition should be done effectively and continuously. Messages given by different sectors should be the same. The messages should be specific, simple and relevant. So the relevant sectors need training materials developed with collaboration and evaluation by the same authority or by a special team. This participation contributes to effectiveness, sustainability and capacitybuilding. In Turkey, a lot of institutions, ministries and universities are giving nutrition education to the public.

\section{Coordination in developing strategies and actions}

All the activities require a clear contribution in building or reinforcing national institutional capacity and could help policy-makers in choosing the priorities in the country. 
The authorities and responsibilities related to many topics are considered by many institutions and it becomes difficult to provide coordination among them. This situation increases the cost of the activities, causes loss of time and manpower, and frequently duplications occur. Every sector is in decision of developing their own Coordination Councils and the members are usually the same.

\section{What is being done in the development of a national plan of action for food and nutrition?}

As is known, the development and implementation of activities demand multidisciplinary and multisectoral coordinated activities. For achieving such collaboration Turkey has trained an adequate number of personnel in relevant disciplines including food, nutrition and dietetics.

In May 2001, under the coordination of the SPO, a Working Committee Report of National Food and Nutrition Strategy for Turkey was prepared with the participation of different sectors working in the food and nutrition area. The report was then published and could be found on the web page of $\mathrm{SPO}^{4}$. The SPO is affiliated to the Prime Minister. Reorganization of the SPO was decided upon by the Council of Ministers on 19 June 1994, based on the authority accorded by Law No. 4004, dated 16 June $1994^{25}$. The main duties of the State Planning Organization are as follows: (1) to advise the government in determining economic, social and cultural policies and targets for the country by taking into account every type of natural, human and economic resources and possibilities of the country; (2) to prepare long-term development plans and annual programmes conforming to the targets determined by the government; (3) to coordinate activities of the ministries and public institutions concerning economic, social and cultural policies, to ensure efficient implementation and advise the government regarding policy issues, etc. $^{25}$

A 'Workshop on Development of Food and Nutrition Action Plans in Southern European Countries' organised by WHO and FAO in March 2002, initiated the activities of the development of a National Plan of Action for Food and Nutrition (NPAFN) for Turkey. To this end, three working groups on food security, food safety and nutrition were established and these groups took the responsibility of developing the action plan and of coordinating studies of the working groups, finalising the NPAFN and monitoring the implementation. First phase of the NPAFN was completed by July 2002. SPO was affiliated as a responsible body for NPAFN.

\section{What are the goal and objectives of the NPAFN?}

\section{Goal}

The goal of the National Food and Nutrition Strategy for Turkey is to protect and promote health through healthy nutrition, reduce the burden of diseases, while contributing to socio-economic development and a sustainable food security ${ }^{4}$.

\section{General objectives}

(1) To show the current situation of Turkey in food security, food safety and nutrition; (2) to make clear the issues in current policy implementation; and (3) to advise, on new policy applications and needs for legislative or administrative changes ${ }^{3}$.

First phase of the NPAFN includes seven actions for food security, seven actions for food safety and 11 main actions and eight related activities for nutrition. For all actions responsible sectors, partners, timing and resources were established for implementation ${ }^{4}$. All the actions for food security and food safety are under the responsibility of the Ministry of Agriculture and Rural Affairs, while the actions for nutrition are shared among the Ministries of Health, Agriculture and Rural Affairs, and Education.

\section{Food security}

(1) For the vulnerable groups, support income and search possibilities for regional support using FIVIMS data, expand alternative products, develop and implement projects for vulnerable groups for income increase; (2) expand TeleFood activities; (3) expand young farmers action plan; (4) expand training for maintaining safe agricultural production and prepare educational materials; (5) prepare and implement comprehensive projects on increasing productivity in animal production (including fishery), give priority to cooperative projects, search possibilities of regional support for adequate subsidy and support facilities, make necessary legislative arrangements to ensure artificial breeding; (6) increase the quality and productivity of the agriculture sector, encourage and assist farmers in input supply, support research; (7) increase production to maintain adequate and balanced nutrition as the priority of agricultural policies.

\section{Food safety}

(1) Prepare in advance the necessary legal arrangements on employment, employment security, obligations, mandates and responsibilities of responsible co-managers working in food enterprises; (2) a provisional article will be included to Decree Law No. 560 for the formation of advisory groups on food to be in force until establishment of an independent and scientific National Food Authority; (3) train middle-level personnel working in food production and preparation, make legal arrangements; (4) train middle-level personnel working in food marketing and mass catering, make legal arrangements; (5) provide trained personnel for food inspection, make legal arrangements; (6) establish a food safety system based on risk analysis from farm to table, promote coordination and cooperation between institutions and establish a National Food Authority; (7) expand food hygiene training 
beginning with milk production hygiene, prepare training materials.

\section{Nutrition}

(1) Conduct a National Food and Nutrition Survey;

(2) establish information and documentation system;

(3) prepare food-based dietary guidelines; (4) provide nutrition education and raise public awareness on nutrition; (5) improve healthy food habits to assure adequate and balanced nutrition, develop school health programmes including food aid and school milk programmes; (6) prevent nutritional problems of risk groups; (7) prevent diet-related chronic diseases; (8) supplementation of diet with vitamins and minerals; (9) fortification of foods; (10) management of nutrition in emergency situations; (11) establishment of a National Food and Nutrition Council (NFNC).

All actions of the NPAFN have detailed sub activities. An example could be given for how the food-based dietary guideline was prepared. This action was the responsibility of the Ministry of Health. The Ministry of Health worked in collaboration with Hacettepe University Department of Nutrition and Dietetics (HUNDD) and the guideline was prepared and sent for approval to related universities, ministries, professional associations, NGOs and others for their comments, before Ministry of Health and HUNDD as an official document (http://www.bdb.hacettepe.edu.tr/ tobrehberi.pdf; http://www.saglik.gov.tr/extras/birimler/ temel/beslenme_rehberi.pdf).

\section{Conclusion}

Food and nutrition policy is defined as a set of coordinated actions, based on a governmental mandate, to ensure the nutritional quality and safety of the food supply, affordable and properly labelled food to all population groups, to promote health and improve dietary habits ${ }^{26-28}$. Food and nutrition policy should not be regarded as detailed proposals for specific programmes but rather as broad policy concerning the effective integration of sectoral policies. In view of the complexity of food and nutrition problems and their intersectoral relationships, it is essential that the food and nutrition policy unit should make the maximum use of the various technical support groups available in the country. A coordinating body is needed for the organisation of food and nutrition policy or allocation of responsibility for coordinating and carrying out a food and nutrition policy.

As a result, in Turkey the NPAFN was developed and implementation has initiated. Nearly for all the actions, related projects are being developed. In the meantime during the implementation process it was seen that every activity creates new ideas and projects. The aim is to keep NPAFN as a living body. For promotion and support of the NPAFN, weaknesses, constraints and successes in the progress of implementation are being monitored.

\section{References}

1 Food and Agriculture Organization/World Health Organization. International Conference on Nutrition. World Declaration and Plan of Action for Nutrition. ICN/92/2, Rome: FAO, 1992.

2 Food and Agriculture Organization. World Food Summit. Technical Background Documents. Rome: FAO, 1996.

3 Pekcan G. Development of nutrition policies: how dietitians are involved in nutrition policies. Beslenme ve Diyet Dergisi/Journal of Nutrition and Dietetics 2000; 29: $24-30$.

4 State Planning Organization (SPO). National Food and Nutrition Strategies (2001). Available at http://www.ekutup. dpt.gov.tr/gida/strateji.pdf (accessed 5 June 2004) (in Turkish)

5 Yücecan S, Pekcan G, Canyürekli G, Kılıçbay S, Çilingiroglu $\mathrm{N}$. A report on nutritional status and its health impacts, Country Report FAO/WHO/ICN, Turkey, 1991.

6 Pekcan G, Budak N, Yüksel B, Toçoğlu N. Country Followup Report. Consultation on International Conference on Nutrition Follow-up in the European Region and Organization for Economic Cooperation and Development Countries, Turkey, 1996.

7 Pekcan G, Karaağaoğlu N. State of nutrition in Turkey. Nutrition and Health 2000; 14: 41-54.

8 Pekcan G, Soydal F, Haznedaroğlu D, Çelik ş, Ekşi A. Nutritional problems of Turkey, importance of food and nutrition policies. Beslenme ve Diyet Dergisi/Journal of Nutrition and Dietetics 2001; 30: 45-57 (in Turkish).

9 Food and Agriculture Organization. Nutrition Country Profiles - Turkey (2001). Prepared in the collaboration of Pekcan G (Turkey) and Marchesich R (ESNA-FAO). Available at http:/www.fao.org/es/ESN/ncp/tur-turmap.pdf (accessed 5 June 2004).

10 Hacettepe University, Institute of Population Studies/Ministry of Health. Turkey Demographic and Health Survey - TDHS. Turkish Demographic and Health Survey - 1998. Ankara, Turkey, 1999.

11 Hacettepe University, Institute of Population Studies/Ministry of Health. Turkey Demographic and Health Survey - TDHS. Turkish Demographic and Health Survey -2003. Ankara, Turkey, 2004.

12 Ministry of Agriculture and Rural Affairs, General Directorate of Protect and Control. Turkey Report on Food Situation, 1317 November, Rome, 1996.

13 Ministry of Agriculture and Rural Affairs, General Directorate of Protect and Control. Food Safety Action Plan in Turkey, Ankara, 2000.

14 Ministry of Agriculture and Rural Affairs. Production, Consumption and Inspection of Food Stuffs. Decree Having the Force of Law No. 560 (24 June 1995).

15 Ministry of Agriculture and Rural Affairs. Production, Consumption and Inspection of Food Stuffs. No. 5179 (5 June 2004).

16 Açkurt F, Wetherilt H, Löker M, Hacıbekiroğlu M. Biochemical assessment of nutritional status in preand post-natal Turkish women and outcome of pregnancy. European Journal of Clinical Nutrition 1995; 49: 613-22.

17 Çetin E, Aydın A. The prevalence and morphological distribution of anaemia in healthy children and adolescents living in İstanbul: the effects of age, gender and nutritional status of children and parental education and economical status on the prevalence of anaemia. Archives of Turkish Paediatrics 1999; 34: 29-34 (in Turkish).

18 Wetherilt H, Açkurt F, Brubacher G, Okan G, Aktas, Turdu S. Blood vitamin and mineral levels in 7-17 years old Turkish children. International Journal for Vitamin and Nutrition Research 1992; 62: 21-9. 
19 Ministry of Health, Directorate of External Relations. Country Health Report. Health Project General Coordination Unit, Ankara, 1997.

20 Turkish Codex for Salt. No. 98/11; 99/8; 2004/25 (9 June 1998; 31 August 1999; 15 August 2000; 7 June 2004).

21 Middle East Technical University/Ministry of Health. Report on the Usage of Iodized Salt in Turkey. Ankara, 2002.

22 Köksal O. A Report of 1974 National Nutrition Health and Food Consumption Survey. Hacettepe University, Ankara, 1977.

23 Tönük B, Gültürk H, Güneyli U, Arıkan R, Kayım H, Bozkurt Ö. 1984 Food Consumption and Nutrition Ministry of Agriculture/UNICEF, Ankara, 1987 (in Turkish).
24 Hacettepe University Department of Nutrition and Dietetics/ Ministry of Health. Food Consumption Survey in 7 Provinces Project Report, Ankara, 1997 (in Turkish).

25 State Planning Organization (SPO). Available at: http:// www.dpt.gov.tr (accessed 5 June 2004).

26 WHO. Nutrition Policy: A Vital Step to Health in Europe. Report on the Conference, Budapest, 1-5 October 1990 (EUR/ICP/NUT 133).

27 WHO. Nutrition Policy Experiences in Northern Europe. Report on a WHO Consultation. Copenhagen, 18-22 January 1988 (EUR/ICP/NUT 134).

28 WHO. Implementation of a Nutrition Policy. Report on a Second Conference on Nutrition in Malta, 24-27 October 1988 (MAT/NUT 001). 